\title{
Trupie podobieństwo
}

Wojciech Michera

TEKSTY DRUGIE 2018, NR 4, S. 333-349

DOI: $10.18318 /$ td.2018.4.20

$\mathbf{W}$ grze, której stawką jest Nietzscheański postulat „zniesienia platonizmu”, zdaniem Deleuze'a kluczowe jest zrozumienie Sofisty. Po pierwsze, ze względu na zawarty w tym dialogu poglądowy wykład ,ikonologii" - relacja między oryginałem a „kopią" lub „pozorem” (czyli dwiema modalnościami „obrazu”) tworzy właśnie fundament platonizmu. Po drugie jednak również dlatego, że sam „Platon jako pierwszy wskazał kierunek zniesienia platonizmu”: „zakończenie Sofisty - pisze Deleuze - zawiera najbardziej niezwykłą przygodę platonizmu: szukając po stronie pozoru i pochylając się nad jego otchłanią, Platon odkrywa, w chwilowym przebłysku, że nie jest on po prostu fałszywą kopią, lecz kwestionuje same pojęcia kopii... i modelu".

Trudno przecenić wpływ Platońskiej teorii dobrych i złych obrazów - "prawdziwych" ikon i "fałszywych" fantazmatów bądź idoli - na dalsze (w Europie) dzieje myślenia. Jeżeli, jak pisze Stephen Halliwell, Sofista
Wojciech Michera

- dr hab., pracuje W Instytucie Kultury Polskiej UW, współredaktor kwartalnika "Konteksty."Zajmuje się teorią obrazu i narracji wizualnej. Tłumaczył m.in. Rolanda Barthes'a, Jacques'a Lacana, Josepha Leo Koernera, Jasia Elsnera, Françoise Frontisi-Ducroux. Autor kilkudziesięciu publikacji, w tym książki Piękna jako bestia. Przyczynek do teorii obrazu (2010). W przygotowaniu: Kobieca sygnatura.

1 G. Deleuze Platon i pozór, przeł. K. Matuszewski, „Principia” 1988, s. 62. 
„proponuje [...] coś w rodzaju filozoficznej «siatki», na której można odwzorować różne rodzaje wykonywanych przez człowieka przedstawień"2, to wypada uznać, że do dziś ulegamy jej symbolicznej przemocy, a cała ikonologia europejska - w jej teorii i praktyce - to istotnie jedynie przypisy do tego Platońskiego dialogu. Działanie Deleuze’a polega więc na znalezieniu słabego punktu w splocie tej sieci i uruchomieniu procedury jej prucia. Jednak ruch oporu wobec platonizmu oznacza też poszukiwanie - w praktykach, teoriach, narracjach - alternatywnych konceptualizacji obrazu, które nie mieszcząc się w schemacie eikon - fantazma, pozostają słabo widoczne, jakby nielegalne, a nawet „kontrwizualne” (w znaczeniu bliskim temu, które Mirzoeff opisał w Prawie do patrzenia) ${ }^{3}$.

Oto dwa przykłady, odległe od siebie w czasie, ale ideowo bardzo bliskie.

*

Pierwszy, który omówię bardzo krótko, pochodzi z Odysei (Homer często bywa dobrą alternatywą dla Platona), z 22 księgi tego eposu. Czytamy w niej o walce, którą Odys, powróciwszy na Itakę, toczy z zalotnikami. Jego sprzymierzeńcem, jak wiadomo, jest Atena, bardzo aktywna w całej tej historii, zachowująca jednak daleko idącą powściągliwość wizualną: pozostaje albo niewidoczna, albo nie pozwala się rozpoznać. W pewnej też chwili czytamy (w. 240), że bogini ta

wzleciała na sczerniałe od dymu sosręby megaronu i usiadła p o d o b n a jaskółce [khelidoni eikele anten - przyp. W.M.]. ${ }^{4}$

W sensie narracyjnym podobne metamorfozy nie są oczywiście niczym dziwnym - uwzględniając realia świata Homeryckiego, widzieć w nich należy przejaw owej przebiegłej mądrości, którą Grecy określali jako metis (Atena zaś to córka będącej jej personifikacją bogini Metis). Tutaj jednak interesuje mnie sam status wizualny bogini, w zacytowanym zdaniu określony za pomocą przymiotnika eikele - dlatego właśnie, że nie daje się go dobrze

2 S. Halliwell The Aesthetics of Mimesis. Ancient Texts and Modern Problems, Princeton University Press, Princeton 2002, s. 65.

3 Zob. N. Mirzoeff Prawo do patrzenia, przeł. M. Szcześniak i Ł. Zeremba, w: Antropologia kultury wizualnej, I. Kurz, P. Kwiatkowska, Ł. Zaremba, Wydawnictwa UW, Warszawa 2011, s 738-746. 
odwzorować na przejętym z Sofisty układzie współrzędnych. Atena, choć wizualnie niczym się zapewne nie różniła od prawdziwej jaskółki, nie stała się przecież prawdziwą jaskółką, przyjęła „jedynie” podobny do niej kształt (słowo „jedynie" biorę w cudzysłów, ponieważ jest ono właśnie symptomem uwewnętrznionego platonizmu). Można powiedzieć: to nie jest jaskółka, to ob raz jaskółki; ale obraz szczególny - ani pozór, ani prawda, raczej coś w rodzaju prawdziwego pozoru. Atena niejako zmienia tryb swojej obecności: jest teraz j a k jaskółka, z mocnym naciskiem na „jak”, istotnie modyfikującym samo „jest”.

W pierwszej chwili sytuacja ta może się kojarzyć ze zwykłą „opozycją rzeczywistości i fantazji (rzeczywistości jak gdyby)", o której pisał Husserl. Według autora Medytacji kartezjańskich „fantazja” wzorowana jest na „prawdziwej" rzeczywistości, czyli powtarza wszystkie modi istnienia, ale przekształcając je i "nadając im charakter czegoś jedynie pomyślanego (danego w akcie myślenia sobie jako coś jak gdyby istniejącego)". Oprócz więc świadomości bycia czymś rzeczywistym istnieją różne modalności świadomości „czysto wyobrażonej n i e - r z e c zy wi s t o ś ci”, np.,świadomości czegoś jak gdyby istniejącego, świadomości fantazjującej"5.

Jednak w interesującej nas scenie z Odysei sprawa jest bardziej złożona. Przede wszystkim nie mamy tu do czynienia z empiryczną („prawdziwą”) rzeczywistością, w której ktoś fantazjuje, lecz z „fantazją” narratora, która wytwarza całą tę rzeczywistość diegetyczną. Nie da się więc wydawać sądów odróżniających prawdę od fałszu, rzeczywistość od fantazji, można jedynie oceniać produktywność języka poetyckiego. Języka, w który domyślnie wpisany jest już zaimek porównawczy ,jak” (czy też partykuły ,; akby”, ,niby”, ,być może" itp.), dokonujący zawieszenia źródłowego sensu, uwalniający komunikat od ewentualnych roszczeń o charakterze referencjalnym. Czytając więc utwór Homera, ju ż jesteśmy zanurzeni w wymiarze „jak-gdyby”, będącym warunkiem i motorem wszelkiej literackiej fikcji ${ }^{6}$.

Tym jednak, co tu najciekawsze, jest przeniesienie zasad tej poetyckiej performatywności na poziom quasi-rzeczywistej diegezy, która sama okazuje się przestrzenią inscenizacji. Tak bowiem działa użyty przez narratora przymiotnik eikele - diagnozujący status wizualny Ateny-jako-jaskółki.

5 E. Husserl Medytacje kartezjańskie, przeł. A. Wajs, P.W.N, Warszawa 1982, Medytacja 3, par. 25, s. 83-84 (zaznaczenia w oryg.).

6 O jego znaczeniu dla Arystotelesowskiej poetyki pisze Paul Ricœur (Czas i opowieść, t. 1: Intryga i historyczna opowieść, przeł. M. Frankiewicz, Wydawnictwo UJ, Kraków 2008, zwł. s. 98). 
Słowo to tłumaczy się jako „podobna” (do jaskółki); jednak, jak pisała Nicole Loraux, w archaicznych tekstach greckich ikelos (eikelos) „nie zawsze zakłada związek podobieństwa między rzeczami lub relację zgodności między obrazem i jego modelem, ale określa czasem ową dziwną mimesis - zapewne przedplatońską - złożoną z tożsamości i uczestnictwa, która charakteryzuje wrażenie prawdopodobieństwa, pozwalając człowiekowi orientować się w świecie znaków"7.

Powiedziałbym, że ikelos przypomina phantasmata z Sofisty, bo oba te terminy kładą nacisk na „wrażenie”, na perswazyjny i odbiorczy aspekt diagnozowanych za ich pomocą obrazów. O ile jednak nazwa phantasma (a poźniej - eidolon) konceptualizuje obraz wizualny jako fał s zy wy (na skutek osłabienia jego zależności od źródłowego modelu), to ikelos zdaje się (jak mawiał Barthes) „subtelniej obchodzić z signifiant”: dzięki niemu uwagę skupia właśnie aspekt performatywny i paradoksalna realność sztucznie wytworzonej zewnętrzności, „realna obecność” tego obrazowego pozoru (co zresztą wcale nie musi go pozbawiać niepokojącej niesamowitości).

\section{$*$}

Drugi przykład, któremu poświęcę więcej uwagi, pochodzi z eseju Maurice'a Blanchota, jednak nie ze Śpiewu syren (z Odysem w roli głównej), lecz z wydanej w 1955 roku Przestrzeni literackiej.

Choć zawarte w tym tomie teksty pisane były przy różnych okazjach, już wstępna nota autorska informuje, że złożona z nich całość tworzy swoiście przestrzenną formę, dublującą niejako zapowiedziany w tytule temat. Czytamy więc, że „Książka, choć pofragmentowana, ma przyciągające ją centrum" - centrum paradoksalne jednak, bo zarazem zmienne, przemieszczające się pod naporem pisania, i stałe, ale coraz bardziej skryte, nieoczywiste i władcze. „Piszący książkę pisze ją pożądaniem, nieznajomością tego centrum"8. Ponieważ jednak w tym wypadku, jak nieco asekuracyjnie stwierdza autor, mamy do czynienia z pracą o charakterze „objaśniającym”, „metodyczna odpowiedzialność” nakazuje wskazanie punktu, ku

7 N. Loraux Les enfants d'Athéna. Idées athéniennes sur la citoyenneté et division des sexes, Éditions La Découverte, Paris 1990, s. 84.

8 M. Blanchot L'espace littéraire, Gallimard, Paris 2005 [1955]. Niedawno ukazał się polski przekład tej książki (Przestrzeń literacka, przeł. T. Falkowski, PWN, Warszawa 2016), tu jednak korzystam z przygotowanego wcześniej własnego tłumaczenia fragmentów książki. 
któremu zdaje się ona kierować; otóż kieruje się „ku stronom zatytułowanym Spojrzenie Orfeusza".

Książka Blanchota ma więc swoje centrum (mówiąc językiem autora: swoją "noc"); warto jednak zauważyć, że jest też okolona swoistą ramą: oto pierwszy z zamieszczonych w nim tekstów (Istotna samotnośc) kończy się obszernym przypisem, który niczym łuk w notacji muzycznej bezpośrednio łączy ten początek z jednym z końcowych aneksów. Otóż w przypisie tym Blanchot zastanawia się nad możliwością utożsamienia języka literackiego i obrazu („czy sam język, w literaturze, nie staje się w całości obrazem? [I nie chodzi o - przyp. W.M.] język zawierający obrazy lub ilustrujący rzeczywistość, lecz o taki, który byłby swoim własnym obrazem, obrazem języka”), pisząc w konkluzji: „zanim pójdziemy dalej, należy zapytać: lecz czymże jest obraz?" I właśnie od tego pytania (Mais qu'est-ce que l’image?) zaczyna się interesujące mnie studium z końcowego aneksu: Les deux versions del'imaginaire.

Rozprawa jest krótka, ale wymaga - podobnie jak cała Przestrzeńliteracka, i jak wszystkie książki Blanchota - niezwykle uważnej lektury. Szczególny zaś kłopot może sprawiać kategoria intrygująco bliska konceptualnie greckiemu ikelon, mianowicie „trupie podobieństwo” (la ressemblance cadavérique). Łatwo bowiem ulec pokusie, by (zapominając nawet o tradycyjnej dwuznaczności moralnej pojęcia similitudo w dawnej teologii chrześcijańskiej) przypisać jej funkcję - tak ją nazwijmy - „konfirmacyjną”, czyli wzmacniającą relację zgodności między obrazem i jego modelem, nasycającą obraz „realnością tego, co przedstawione", jak pisze Godfried Boehm w duchu Gadamerowskiej ontologii obrazu9. A że takie nieporozumienie jest możliwe, świadczy przykład Hansa Beltinga, innego wybitnego niemieckiego historyka i teoretyka sztuki, który w rozważaniach na temat genezy obrazu powołuje się właśnie na Blanchota i jego Les deux versions de l'imaginaire. Sytuacja ta daje sposobność, by komentując błąd Beltinga, poglądowo objaśnić samego Blanchota.

9 G. Boehm Przyrost bytu. Refleksja hermeneutyczna a sztuki plastyczne, w: tegoż O obrazach i widzeniu. Antologia tekstów, red. D. Kołacka, Universitas, Kraków 2014, s. 105. Por. H.-G. Gadamer Prawda i metoda. Zarys hermeneutyki filozoficznej, przeł. B. Baran, Inter esse, Kraków 1993. Przy okazji: Gadamer pisze wprawdzie (s. 153.), że „platońska relacja pojęć podobizny [Abbild] i pierwowzoru [Urbild] nie wyczerpuje bytowej wartości tego, co zwiemy obrazem", ale nie sądzę, by istotnie w proponowanej w zamian przez niemieckiego filozofa pojęciu "reprezentacji" należało widzieć rzeczywiste podważenie platońskiej ikonologii. Zob. W. Michera "I nie było już nikogo...". Obraz jako trop, "Konteksty” 2016 nr 3/4, s. 100-106. 
Chodzi przede wszystkim o pracę Beltinga Obraz i śmierć, włączoną jako rozdział do poczytnej i tłumaczonej na wiele języków Antropologii obrazu ${ }^{10}$. Niemiecki uczony przedstawił w niej swoją wizję historycznych początków obrazu oraz funkcji, jaką miał on pełnić „we wczesnych kulturach” (takiego określenia używa Belting, ale lepiej chyba powiedzieć: w pojmowanym ahistorycznie modelowym „społeczeństwie pierwotnym”). Zastanawiając się zatem nad rolą, , ,jaką doświadczenie śmierci odegrało w powstaniu obrazów"11, Belting stwierdza, że stały się one narzędziem, które pozwalało zapanować nad grozą śmierci: „śmierć jest nieobecnością nie do zniesienia, chce się ją zatem wypełnić obrazem, aby można ją było znieść". Właśnie dlatego ludzie stworzyli

obraz, za pomocą którego na swój sposób czynili sobie śmierć, to, co niezrozumiałe - zrozumiałym. Teraz to był ich własny obraz, który mogli przeciwstawić obrazowi śmierci, zwłokom.

Zdaniem Beltinga jednak sytuacja ta stwarzała inny, i to zasadniczy problem, bowiem „otwiera się tutaj zagadka bytu i pozoru", czyli kłopotliwy rozziew między prawdziwym bytem, jakim jest żywy człowiek, i ontycznym pozorem mającego zastąpić go obrazu. Otóż rozwiązaniem stać się miała przekazywana obrazowi „moc występowania w imieniu i na miejscu ciała” - dzięki np. obrzędom religijnym otrzymywał on

autorytet nowego rodzaju. Obraz [w uogólnionym „kulcie zmarłych”] był nie tylko kompensatą, ale zyskiwał w akcie zastępowania „byt”, który

10 Por. H. Belting Antropologia obrazu. Szkice do nauki o obrazie, przeł. M. Bryl, Universitas, Kraków 2007, rozdział Obraz i śmierć (dalsze cytaty z tej książki pochodzą ze stron 171-177).

Belting zastrzega, że jest to tylko jedna z możliwych wersji tej genezy, bowiem: „Istnieją całkiem inne korzenie obrazu, takie jak przedstawienia zwierząt na ścianach jaskiń z epoki kamiennej lub idole ze znakami żeńskiej płodności" (s. 176). Nie ma tu miejsca, by wyczerpująco skomentować tę lakoniczną deklarację, ale niewątpliwie jej treść prowokuje do postawienia wielu zasadniczych pytań: czy chodzi w tym wypadku o zupełnie odrębny proces kulturowy?; w jakim sensie "przedstawienie zwierząt" może stanowić „korzeń" obrazu?; czy chodzi tu o jakiś impuls mimetyczny, będący alternatywą dla domniemanej "grozy śmierci” w "kulcie zmarłych"?; jak rozumieć w tym kontekście kategorię „żeńska płodność", należącą wprawdzie do potocznego słownictwa dawnej archeologii, bynajmniej jednak nie tak oczywistą?; czy artefakty kulturowe, powstające w wyniku takich niezależnych procesów kulturowych i wykorzystywane w odmiennych praktykach, z równie mocnym uzasadnieniem można nazywać "obrazami"?; etc. 
reprezentował w imieniu ciała, nie będąc jednak obalonym przez pozór, na którym [jako obraz - przyp. W.M.] opierał swoje działanie.

Koncepcja Beltinga zakłada więc, że obraz: po pierwsze, zastępuje w praktyce społecznej ciało zabrane przez śmierć, gwarantując „obecność zmarłego w miejsce nieobecnego ciała”; po drugie zaś, że - w ramach tej samej praktyki - przekracza swoją własną bytową słabość, czyli przyrodzoną niejako niekompletność i nierealność. Ta postgadamerowska zasada (umownej, usankcjonowanej społecznie) tożsamości bytowej obrazu i jego modelu przyświeca Beltingowi we wszystkich jego pracach. We wstępie do książki Obraz i kult czytamy np.: „przez obraz rozumiemy w naszych rozważaniach przede wszystkim wizerunek osobowy, imago. Imago przedstawiało zazwyczaj osobę i dlatego traktowano je również jako osobę. Tak pojmowane, stało się ulubionym przedmiotem praktyk religijnych. [...] «Sztuka», jak pragnie ją tu rozumieć autor, zakłada kryzys dawnego obrazu [...] Można teraz mówić o pewnej e p o c e sztuki, trwającej do dzisiaj. Poprzedziła ją e p oka o bra z u"12. Deklaracja ta odnosi się oczywiście do pewnej rzeczywistości historycznej i historycznie poświadczonych praktyk - które Belting opisuje na kilkuset dalszych stronach swego dzieła. Zarazem jednak zarysowana tu diachroniczna logika upadku (epoka obrazu $v$. kryzys obrazu w epoce sztuki) zakłada określoną aksjologię i wiąże się z tym, co autor „rozumie przez obraz”, a co wynika z Gadamerowskiego założenia mówiącego o „bytowej kontynuacji”, pozwalającej na praktykowanie „estetycznej nieodróżnialności” obrazu i przedstawionej na nim osoby. To zaś, co odnosi się do tak późnego w dziejach ludzkości okresu, jak koniec starożytności lub średniowiecze (schyłek „epoki obrazu”), w jeszcze większym stopniu charakteryzuje czasy "pierwotne" (początek tej epoki). Warto przypomnieć, że zdaniem Gadamera najlepszym przykładem prawdziwego obrazu, jest „obraz magiczny”, który „występuje tylko na początku dziejów obrazu, należąc niejako do jego prehistorii”, co jednak nie oznacza, że dzisiejsza „świadomość obrazu, która się w rosnącym stopniu oddala od magicznej tożsamości, może się kiedyś od niej zupełnie oddzielić. Raczej nierozróżnianie pozostaje istotowym rysem wszelkiego doświadczenia obrazu"13.

12 H. Belting Obraz i kult. Historia obrazu przed epokg sztuki, przeł. T. Zatorski, słowo/obraz terytoria, Gdańsk 2012. 
W swoich spekulacjach zatem na temat "początku dziejów obrazu” Belting pozostaje wierny Gadamerowi, wzmacniając jedynie aspekt społeczny i psychologiczny, podkreślając przede wszystkim znaczenie grozy, jaką w pierwotnym człowieku musiała wywoływać śmierć - gdy oddychające i mówiące ciało nagle zamienia się w będące niemym obrazem zwłoki. Zdaniem Beltinga obraz wytworzony przez człowieka w ramach „kultu zmarłych” sam był jak śmierć i wkraczał w jej miejsce. Nad nim jednak, nad tym „symbolicznym ciałem", inaczej niż nad rzeczywistą śmiercią i prawdziwymi zwłokami, można było zapanować. Dzięki temu zaś, jak czytamy w Antropologii obrazu, „społeczna przestrzeń poszerzała się - poprzez obrazy i odprawiane z ich udziałem rytuały - o przestrzeń zmarłych".

\section{*}

To jest właśnie miejsce, w którym Belting - pisząc o podobieństwie obrazu i śmierci - powołuje się na tekst Maurice'a Blanchota Dwie wersje wyobrażonego, komentując go dość obszernie i traktując jako teoretyczne wsparcie własnej koncepcji. Czytamy więc m.in.:

obraz wcielający zmarłego staje się przeciwieństwem owego innego obrazu, jako który prezentują się same zwłoki. Zwłoki ze swej strony stawały się w chwili śmierci zastygłym obrazem, już tylko podobnym do żywego ciała. Dlatego Blanchot mówi, że „zwłoki są swoim własnym obrazem”. Nie są już ciałem, ale tylko obrazem ciała. [...] Dawne ciało zamienia się w obraz samego siebie.

Otóż Blanchot istotnie pisze: „trup jest swoim własnym obrazem” (le cadavre est sa propre image); chwilę wcześniej zaś: „opłakiwany nieboszczyk zaczyna być podobny do samego siebi e" (commence à ress embler à lui-même). Nie znaczy to jednak, co sugeruje Belting, że według Blanchota trup zamienia się w obraz dawnego, żywego ciała (,już tylko" do niego podobny)! Przeciwnie, autor Przestrzeni literackiej pisze wprost: nie chodzi o podobieństwo nieboszczyka „do tego, kim był, gdy żył”. Dlatego zdanie „trup jest swoim własnym obrazem” należy rozumieć absolutnie dosłownie: trup jest obrazem trupa, czyli nie ma w nim innego odniesienia niż on sam. Dlatego właściwe mu „podobieństwo” (la ressemblance), łącznie z jego by tową słabo ścią, która tak niepokoiła Beltinga, niejako autonomizuje się i nabiera szczególnego sensu. Blanchot: 
jeśli trup jest tak podobny, to dlatego, że jest, w pewnej chwili, podobieństwem par excellence, całkowicie podobieństwem, i niczym więcej. Jest czymś podobnym [le semblable], podobnym w stopniu absolutnym, wstrząsającym i cudownym. Do czego jednak jest podobny? Do niczego $[$ A rien $]{ }^{14}$

Nie ma więc też podstaw, by (powołując się w każdym razie na Blanchota) "obraz", który dostrzegamy w trupie, przeciwstawiać artefaktowi wykonanemu rękami ludzkimi, traktowanemu teraz jako „wcielenie” zmarłego i będącemu jego poręczniejszym, „symbolicznym ciałem”, mającym skuteczniej posłużyć jego „resocjalizacji”. Nie o poręczność bowiem Blanchotowi chodzi, lecz o „niesamowitość":

[choć] obraz, na pierwszy rzut oka, nie jest podobny do trupa, możliwe jednak, że niesamowitość trupia jest też niesamowitością obrazu. ${ }^{15}$

"Trupie podobieństwo” - odpowiadające owej „niesamowitości” - jest traktowane tu jako nieredukowalna własność obrazu i odpowiada w nim za to, co radykalnie nieuchwytne, a zarazem nieuniknione (i co nieprzypadkowo Blanchot określa też jako „nawiedzenie”, hantise). Można rzec, że to ono (trupie podobieństwo) stanowi o osobliwej "potędze obrazu” - innej jednak niż ta, którą zajmują się tacy badacze jak właśnie Belting lub Freedberg, ni e sł u ży bowiem zapanowaniu nad grozą śmierci, sakralizacji nieboszczyka, symbolicznemu uobecnieniu nieobecnego "prototypu”, ustanowieniu s e n s o w n e j kohabitacji żywych ze zmarłymi. Przeciwnie! Przypomina raczej siłę, która (jak czytamy w Spojrzeniu Orfeusza, owym centralnym tekście Przestrzeniliterackiej) zmusiła trackiego pieśniarza, by zszedłszy do otchłani, wbrew zakazowi, odwrócił się ku Eurydyce. Nie jest to chęć ujrzenia zmarłej „w prawdzie dnia i codziennym wdzięku”, lecz „,w mroku nocy, w oddaleniu”,,,jako obcości tego, co wyklucza wszelką zażyłość” - nie jest pragnieniem „ożywienia jej, lecz zachowania w niej żywej pełni jej śmierci"16.

Zauważmy więc, że - na tej samej zasadzie - nawet jeśli oglądamy obraz w jasnym świetle dnia, przypomina on raczej zjawę nawiedzającą żywych,

M. Blanchot Les deux versions de l'imaginaire, w: L'espace littéraire, s. 347.

15 Tamże, s. 344.

16 M. Blanchot Le regard d'Orphée, w: tegoż L'espace littéraire, s. 226. 
i to wbrew ich woli; upiora, który rzucając swój trupi cień na ludzką egzystencję, odbiera jej pewność znaczeń, wprowadza nieusuwalny dystans, oddalenie, rozkład, „obecność nieobecności” (co akurat dobrze znamy dzięki twórczości Tadeusza Kantora).

Choć więc refleksja Blanchota i Beltinga rozgrywa się w podobnej na pierwszy rzut oka, trupiej scenerii, deklarowana przez tego drugiego bliskość ideowa obu koncepcji jest nieporozumieniem; w każdej z nich zresztą najistotniejsze wydaje się właśnie to, co je różni. Najdziwniejsze zaś, że właśnie tej różnicy, pozwalającej wyodrębnić „dwie możliwości obrazu” (deux possibilités de l'image), poświęcone jest studium Blanchota ${ }^{17}$ !

Pierwsza zatem "możliwość”, jaką stwarza obraz (dopowiedzmy: w szeroko pojmowanej przestrzeni praktyk społecznych), wynika ze skonstatowania pewnej oczywistości, że mianowicie obraz jest wtórny w stosunku do obiektu, że przychodzi „po” nim, co oznacza, że „najpierw rzecz musi się oddalić, by można ją było ponownie uchwycić". Obraz staje się więc re-prezentacją rzeczy, wtórną wobec niej i podporządkowaną bytowo, pozwalającą jednak owe rzeczy, gdy są nieobecne, uchwycić i nimi dysponować (także za pomocą literackiej fikcji, która „utrzymuje nas w bogatym horyzoncie sensu”). Działa tu ta sama zasada, która (według Blanchota) każe rozumieć „słowo poetyckie” jako cień, transpozycję potocznego języka, dokonującą się „w przestrzeni, w której ulegają złagodzeniu wymagania dotyczące jego skuteczności”.

Bez wątpienia koncepcja Beltinga, mimo pewnego jej zagmatwania terminologicznego ${ }^{18}$, jest przykładem tej pierwszej „możliwości obrazu” - obrazu

17 Należy tu wyjaśnić, że Blanchot używa wymiennie terminów "wyobrażone" (I'imaginaire) i „obraz" (l'image), w czym widać wpływ fenomenologii Sartre'a: chodzi zawsze o złożoną relację między podmiotem i światem, o "formę świadomości". Warto przypomnieć początek rozdz. 2 książki J.P. Sartre’a Wyobrażenie: „Opisaliśmy [w rozdziale 1.] różne formy świadomości, zwane wyobrażeniami. Nie wiemy jednak, gdzie zaczyna się i gdzie kończy się klasa wyobrażeń. Istnieją np. w świecie zewnętrznym przedmioty zwane obrazami; są to portrety, odbicia w lustrze, naśladownictwa itd. Czy chodzi tu o zwykłą homonimię, czy też postawa naszej świadomości wobec tych przedmiotów jest porównywalna z tą, jaką zajmuje ona w «wyobrażeniu umysłowym»? W tym wypadku należałoby poważnie poszerzyć pojęcie wyobrażenia, aby włączyć doń wiele świadomości, które nie były dotąd brane pod uwagę", J.-P. Sartre Wyobrażenie. Fenomenologiczna psychologia wyobraźni, przeł. P. Beylin, PWN, Warszawa, s. 39.

Wiadomo, że każdy język ma swoje ograniczenia, które uniemożliwiają wyrażenie w nim radykalnie nowej myśli (jest to podstawowy problem, którym zajmowała się dekonstrukcja). Odnoszę jednak wrażenie, że z Beltingiem jest trochę odwrotnie: wprowadza on do swojego dyskursu pojęcia zaczerpnięte z "nowego języka” (np. z Blanchota, z Derridy), ale po to, by przechować w nich stare, metafizyczne treści. Wytwarza to niekiedy kłopotliwy dysonans poznawczy. 
pojmowanego jako wypełnienie braku pojawiające się „po" obiekcie, którym jest zmarły. Dzieje się to w rzeczywistości społecznej, która mocą swoistej umowy „konfirmacyjnej” (np. religijnej, obrzędowej) łagodzi wymagania dotyczące bytowej „skuteczności” i przyznaje obrazowi bytową realność.

Ale takie pojmowanie obrazu, choć w pewnym zakresie badań kulturoznawczych wydajne poznawczo, stanowi też pułapkę. Jeśli damy się w nią schwytać, przeoczymy tę cechę obrazu, którą jest jego „dwoistość” czy też "przewrotność" (duplicité); jak zaś pisze Blanchot w L'Entretien infini, „obraz jest obrazem [dopiero] w tej właśnie dwoistości”ı . Druga zatem „możliwość obrazu” wyłania się w chwili, gdy kategorię „po” (lub „oddalenia”) pozbawimy prostej funkcji opisowej, opisowej przejrzystości, i uwagę skupimy na niej samej; stawką bowiem jest właśnie właściwa jej negatywność (scil. „pozór”). O ile dla Beltinga była ona jedynie przykrą i wymagającą stosownej ekspiacji przypadłością, teraz staje się nieusuwalną właściwością obrazowego „jest” (zarazem owo „jest” radykalnie osłabiając, czyli wpisując w ontologię obrazu nieredukowalny paradoks widmowego nawiedzenia).

„Po" oznacza, że najpierw rzecz musi się oddalić, by można ją było ponownie uchwycić. Lecz oddalenie to nie jest prostą zmianą miejsca czegoś, co poruszając się, pozostaje jednak tym samym. To oddalenie jest tu sednem sprawy. Rzecz tam była, co pojmujemy w żywym ruchu rozumiejącego działania - i zmieniwszy się oto w obraz natychmiast staje się nieuchwytna, nieaktualna, bierna; nie staje się tą samą rzeczą w oddaleniu, lecz ową rzeczą jako oddaleniem, obecną w nieobecności, uchwytną dlatego, że nie daje się uchwycić, pojawiającą się jako zaginiona, powrotem tego, co nie powraca $[\ldots]^{20}$

M. Blanchot L'Entretien infini, Gallimard, Paris 1969, s. 40. Dlatego Marie-Claire Ropars-Wuilleumier pisała (w książce L'idée d'image, w rozdziale nieprzypadkowo zatytułowanym Duplicité de l'image): „jeśli obrazy się różnią - od cyfrowych po pikturalne - to czy nie zamaskuje to własnej różnicy obrazu, mnogiego z samej definicji?" (L'idée d'image, Presses Universitaires de Vincennes, Saint-Denis 1995, s. 8). A już zupełnie na marginesie: w porządku praktyk społecznych, które są przedmiotem zainteresowania studiów nad kulturą wizualną, antropologia obrazu Beltinga odnosi się raczej do tego, co Nicholas Mirzoeff określa w Prawie do patrzenia jako Wizualność I niż do Wizualności II, a zwłaszcza Kontrwizualności. Z kolei ta właściwość obrazu, którą Blanchot nazywa „trupim podobieństwem”, wskazuje na zawarty w obrazie autodekonstrukcyjny potencjał kultury. 
Nie jest więc łatwo uchwycić różnicę między jedną i drugą „możliwością" obrazu, nie tworzą one bowiem prostej alternatywy. Niezbędne staje się tu uchwycenie samego „pomiędzy”, do tego zaś potrzeba (mówiąc językiem Blanchota) spojrzenia Orfeusza: należy „patrząc w noc, wypatrywać tego, co noc ukrywa, in nej nocy, pojawiającego się w niej ukrycia"21. Powtórzę: te dwie noce nie tworzą symetrycznego, dwuargumentowego układu, w którym oba elementy mogą się zastępować. „Innej nocy” trzeba wypatrywać w nocy pierwszej, ale nie jako kryjącej się w niej „istoty” lub „pełni”, lecz jako samego „ukrycia” (czy też, w terminologii Derridiańskiej, „krypty”), którego zatem nie da się zobaczyć „tak samo”, tak samo „skutecznie” (choć przecież nawet zwykła noc, podobnie jak w psychoanalizie zwykła nieświadomość, w swojej negatywności łatwo się naszemu poznaniu nie poddaje).

Ten paradoks wymaga kłopotliwego dla świadomości przeostrzenia uwagi. Ale ponieważ jest on kluczowy dla myśli Blanchota (i szerzej: dla pewnego sposobu konceptualizacji obrazu), spróbuję go objaśnić, posługując się fragmentem innego utworu Blanchota.

\section{$*$}

Wstęp do L'Entretien infini, wyróżniony w książce rzymską paginacją, ma formę literackiej narracji przedstawiającej dziwną rozmowę dwóch starych mężczyzn. Padają w niej następujące słowa:

Jak pan wie, od pewnego czasu jestem bardzo zmęczony. Nie należy zbytnio zważać na to, co miałbym do powiedzenia. To zmęczenie skłania mnie do mówienia; jest to najwyżej prawda zmęczenia. Prawda zmęczenia, zmęczona prawda. ${ }^{22}$

Jak rozumieć tę deklarację, mającą pewne cechy logicznej antynomii? Jako przejaw zwiastującego katastrofę psychicznego zwątpienia? Czy z tych słów istotnie wynika, że nie są one warte uwagi? A może ta pozorna kokieteria jest raczej próbą szczególnej konceptualizacji języka, wskazującej na „niemoc” jako ważną i nieusuwalną jego cechę? Jeśli tak, to absurdalna z pozoru prośba, by „nie zważać zbytnio na to, co miałbym do powiedzenia”, okazałaby się raczej przewrotną (metajęzykową) sugestią metodologiczną. Miałaby

M. Blanchot Le regard d'Orphée, 226-227. 
ona mniej więcej taki sens: skoro moje słowa biorą się ze „zmęczenia”, to tej szczególnej ich k o n dy cj i nie wolno pomijać; nie może więc być właściwą postawą poznawczą "nadmierna uwaga”, usiłująca wydobyć „prawdziwe” treści ukryte za tą deformacją.

Zwróćmy zwłaszcza uwagę na ów niuans, grę słów iskrzącą jako różnica między la vérité de la fatigue i une vérité fatiguée. Tylko pierwszą z tych formuł można zrozu mi eć - jako informację o racjonalnej, psychologicznej przyczynie skutkującej np. pogorszeniem się jakości autorskiej wypowiedzi. Formuła druga jest raczej poetycką metaforą albo opartą na chiazmie zabawą. Ale takie przekształcenie statusu zmęczenia z (zewnętrznej) przyczyny w (wewnętrzną) właściwość ma swoje konsekwencje logiczne. „Zmęczona prawda”, wpisując niejako w swoje DNA kasandryczny program samopodważania, jako pojęcie staje się (tak samo jak „czyste podobieństwo”, podobieństwo „do niczego") rodzajem semantycznego bękarta, odwlekającego w nieskończoność zrozumiały sens. To bowiem, co bękarcie (nieprawe, nieuprawnione), "daje się ująć - jak mówił Platon - tylko bękarcim rozumowaniem" (Tim. 52b, 2-3). Dlatego też „zmęczona prawda” Blanchota wymaga równie „zmęczonej” uwagi, czyli takiej, która nie dąży do przywrócenia jej kondycji i zdrowia. Przypomina więc marzenie senne, którego złożona ontologia wymaga od psychoanalityka skupienia uwagi nie tyle na treści, ile na broniących dostępu do tej treści zniekształceniach. W konsekwencji „zmęczona prawda" upodabnia się też do żółwia, za którym beznadziejnie goni Achilles; a dokładniej - do Bryzeidy, która jako obiekt popędu zastępuje żółwia w Lacanowskiej wersji paradoksu Zenona; otóż zawsze pozostaje ona "nie-cała” (pas-toute), nie cała dla n i e g o ${ }^{23}$. Ktoś mógłby nawet powiedzieć, że po prostu „nie istnieje”.

*

Wracając zatem do Dwóch wersji wyobrażonego - „druga możliwość obrazu” jest obecna w "pierwszej” trochę tak, jak „zmęczenie” w słowach starego człowieka, jako ich swoista wibracja, albo po prostu drżenie - rąk, głosu - niwelujące złudną oczywistość zakomunikowanych mniemań. Co ciekawe, o „zmęczonym myśleniu" jako efekcie starości piszą też Deleuze i Guattari, ale u nich oznacza to „albo upadek w mentalny chaos, poza płaszczyzną kompozycji, albo ograniczenie się do istniejących już mniemań, klisz, świadczących o tym,

23 Por. J. Lacan Le Séminaire de Jacques Lacan, Livre XX, Encore, Éditions du Seuil, Paris 1975, s. 15 (paginacja według wydania z roku 2005). 
że artysta nie ma już niczego do powiedzenia, ponieważ nie jest w stanie tworzyć nowych wrażeń”.Tymczasem „wrażenie” jest „pobudzeniem”, twórczą reakcją na chaos: „wrażenie samo wibruje, ponieważ wiąże wibracje”24 etc. Nie chcę się długo zatrzymywać przy rozważaniach Deleuze'a i Guattariego, ale jeśli szukalibyśmy w nich jakiejś analogii dla „zmęczonej prawdy” Blanchota, to niekoniecznie byłaby ona skutkiem „zmęczonego myślenia”, może więcej nawet miałaby wspólnego właśnie z owym „wibrującym wrażeniem”.

Według zatem Dwóch wersji wyobrażonego obraz może, z jednej strony, mówić o świecie: daje nam „możliwość dysponowania rzeczami, gdy są nieobecne, za pomocą fikcji utrzymując nas w bogatym horyzoncie sensu". Jednak z drugiej - w samym jego sercu zawiera się ów szczególny punkt, ku któremu, wbrew zakazowi, zwrócił się Orfeusz, zaprzepaszczając szansę na sukces, czyli na konkluzywne ukończenie podjętego dzieła. Blanchot mówi: „nieokreślone środowisko fascynacji” - „rzeczy są [w nim] zapewne obecne, ale w swoim obrazie, obraz zaś jest momentem bierności, nie ma żadnej wartości znaczeniowej lub afektywnej, jest namiętnością obojętności". Tutaj sens obrazu (sensowny obraz) przekształca się - ale nie w jakiś inny, bliższy prawdy sens, lecz w „i n n e wszelkiego sensu”:

nic nie ma sensu, wszystkojednak wy d aje s i ę mieć sens nieskończony: sens jest już tylko czymś podobnym, podobne sprawia, że sens staje się nieskończenie bogaty ${ }^{25}$.

Widz stojący przed obrazem (a także czytelnik wobec powieści i śniący wobec swojego snu - te trzy domeny są dla Blanchota nierozdzielne) ma zatem dwie możliwości wynikające z tego, „czym jest” albo raczej - „jak jest”,jak to jest z obrazem. Znajduje się w sytuacji Orfeusza wobec Eurydyki albo też - jeśli zstępowanie w otchłań nocy uznamy za zbyt radykalną metaforę naszej codzienności - Jezusa, który stojąc p r z e d grobem Łazarza woła: Lazare, veni foras! ${ }^{\mathbf{2 6}}$.Tak samo bowiem, jak są dwie „noce” (jedna skryta w drugiej, i będąca tym właśnie ukryciem), tak też zdaniem Blanchota jest dwóch Łazarzy: ten, który ukazuje się oczom widza-Jezusa - zmartwychwstały, przywrócony

G. Deleuze, F. Guattari Co to jest filozofia, przeł. P. Pieniążek, słowo/obraz terytoria, Gdańsk 2000, s. 236-237. 
jasności dnia, i ten, który się kryje pod lśniącymi szatami - cuchnące jeszcze, rozpadające się trupie ciało. Jeżeli za obraz (książkę, sen) uznamy grób, to wyłaniający się z niego Łazarz byłby jego z n a c z e n i e m. W pierwszej więc swej postaci pozwala z r o z u m i e ć: jest przedstawieniem rzeczy w zrozumiałym języku, co zapewnia funkcjonowanie obrazu w jawnym obiegu społecznym. Drugi, jako mroczna, trupia rzeczywistość, stawia interpretacji opór, niczego jednak w zamian, poza samym tym oporem, poza anonimową nieprzejrzystością krypty-obrazu, nie ofiarowując. Powiedziałbym więc, idąc za nieco swobodniej tu przywoływaną myślą Blanchota, że trupiość (Łazarza, podobieństwa) stanowi swoiste residuum, nieredukowalną obcość, której w żaden sposób (nawet za pomocą społecznej umowy, jak chciałby Belting) nie można zadomowić w stabilnym obszarze ontologii lub wiedzy.

Temat podobieństwa, także „trupiego", powraca w podobnym ujęciu w eseju Śnić, pisać Blanchota (będącym wstępem do książki Leirisa Noce bez nocy, wydanej w 1961 roku):

Ktoś, kto nagle zaczyna kogoś „przypominać”, wycofuje się z realnego życia, przechodzi do innego świata, wkracza w niedostępne są s i e d z t wo o b r a z u, i jakkolwiek jest obecny, obecnością nie własną ani nie cudzą, jest p o z o r e m [wyróż - W.M], który pozostałych obecnych obraca w pozór. I to podobieństwo, w czasie - czasie bezkresnym - w którym się objawia, nie jest nieokreśloną więzią z tą czy inną osobą; jest czystym i zwyczajnym podobieństwem, jakby neutralnym. ${ }^{27}$

W opisie tym, odnoszącym się też oczywiście do podobieństwa trupiego, najciekawsze jest właśnie to, że nie zakłada on koniecznej obecności prawdziwych zwłok (mogących wywoływać psychologiczny strach), lecz odnajduje „drugą możliwość" obrazu w tzw. realnym świecie. Jeśli bowiem dzięki tak rozumianemu podobieństwu istotnie wkraczamy w „sąsiedztwo obrazu”, jak mówi Blanchot, to z pewnością nie chodzi o ten obraz, który jako symboliczny substytut życia pozwalałby zapanować nad śmiercią i przywracał społeczny ład. Jest raczej odwrotnie - pozwala on in a c z ej mówić o życiu, uwzględniając to, co w nim radykalnie in $\mathrm{n}$ e, a co bierze się z zatrzymania, unieruchomienia, będącego symptomem śmierci, otwierającego w potoku życia niewyczerpany cudzysłów („bezkresne migotanie odbicia”). Jeśli mielibyśmy

27 M. Blanchot Śnić, pisać, wstęp w: M. Leiris Noce bez nocy, przeł. A. Wasilewska, słowo/obraz terytoria, Gdańsk 2011, S. 12. 
więc przypisywać temu obrazowi jakąkolwiek funkcję substytucyjną, to tylko w znaczeniu owej niekończącej się "gry substytucji”, inicjowanej przez „mechanizm suplementarności”, który Derrida odkrył w samym centrum filozoficznego pojęcia struktury. Wtedy „trupiość” obrazu, jako „czyste podobieństwo", byłaby „swego rodzaju nie-miejscem, w którym rozgrywają się w nieskończoność podstawienia znaków"28.

Ponownie przypomina to sposób, w jaki funkcjonuje marzenie senne, o którym Blanchot tak pisał w Le sommeil, la nuit (jeszcze jednym dodatku do L'espace littéraire):

dociera [ono] do strefy, w której króluje czyste podobieństwo. Wszystko jest tam podobne, każda twarz jest inną twarzą, podobną do innej, i jeszcze do innej, ta zaś do kolejnej. Wypatrujemy pierwotnego modelu, chcielibyśmy powrócić do punktu wyjścia, do początkowego objawienia, ale go nie ma: w marzeniu sennym podobne w nieskończoność odsyła do innego podobnego. ${ }^{29}$

Zgodnie z tą logiką Blanchotowskie podobieństwo - z definicji "trupie” odpowiedzialne za wyjątkową naturę „obrazu” (tak czy inaczej - wizualnego), należałoby rozumieć jako swoistą formę, w istocie zaś źródłową de-formację, która niczym stopklatka w filmie dokonuje zawieszenia sensu, ujawniając i to jako stan źródłowy - owo „jak”, ,jak gdyby” „dziwnej mimesis” określanej przez Greków jako ikelon.

\footnotetext{
$*$

Najciekawszym chyba przykładem użycia słowa ikelos, niedającego się udomowić przez „wizualność" projektowaną na siatce konceptualnej Sofisty, jest zdanie opisujące paradoksalną kondycję pierwszej kobiety, Pandory, powtórzone przez Hezjoda dwukrotnie, w Theogonii i w Pracach i dniach. Mówi ono mianowicie, że z woli syna Kronosa Hefajstos ulepił „istotę podobną dziewczynie” czy też „formę wstydliwej dziewczyny” (na te dwa sposoby zdanie to tłumaczy Jerzy Łanowski). W każdym razie pojawia się tu greckie sformułowanie: partheno aoide ikelon. Dlaczego Hezjod nie napisał po prostu, że

28 J. Derrida Struktura, znak i gra w dyskursie nauk humanistycznych, w: Pismo i różnica, przeł. K. Kłosiński, KR, Warszawa 2004, s. 485-486. 
Hefajstos stworzył kobietę? „Kim zatem jest kobieta?” - pyta Nicole Loraux „Fałszywą kobietą? Nie. Jest kobietą w tej mierze, w jakiej kobietę przypomina [...]. Kobieta: kopia samej siebie. Ikelon, kobieta jest podobieństwem. Lecz podobieństwem kopii bez pierwowzoru ${ }^{30}$.

\section{Abstract}

\section{Wojciech Michera}

UNIVERSITY OF WARSAW

\section{Cadaverous Resemblance}

Plato's dialogue the Sophist distinguishes between 'true' copies or eikones and 'false' simulacra or phantasmata. This distinction has had an immense influence on the history of European 'iconology'. Michera, however, takes up Nietzsche's vehement anti-Platonism and proposes two alternative concepts of the image. The first is the word eikelos as used by Homer and Hesiod. The second, discussed in more detail, is the 'cadaverous resemblance'from Maurice Blanchot's text"Les deux versions de l'imaginaire."A particular opportunity to reflect on Blanchot's concept - which is conceptually intriguingly close to the Greek ikelon - appears in Hans Belting's misleading interpretation as presented in Anthropology of Images.

\section{Keywords}

image, ikelos, cadaverous resemblance, Plato, Maurice Blanchot, Hans Belting

30 N. Loraux Les enfants d'Athéna..., s. 86-87. O Pandorze i jej szczególnej kondycji piszę nieco więcej w książce Piękna jako bestia. Przyczynek do teorii obrazu, Wydawnictwa UW, Warszawa 2010 (rozdział Prometheus) oraz w artykule Myślenie w perspektywie bezdomności. 'Daidalos', 'kharis', 'ikelos', „Konteksty” 2017 nr 1/2, s. 121-130. 